\title{
THE KNOWLEDGE OF A SELECTED GROUP OF MEDICAL STUDENTS ON HYPERBARIC OXYGEN THERAPY
}

\author{
WIEDZA WYBRANE] GRUPY STUDENTÓW MEDYCYNY W ZAKRESIE TLENOTERAPII \\ HIPERBARYCZNE]
}

\section{ЗНАНИЯ ИЗБРАННОЙ ГРУППЫ СТУДЕНТОВ-МЕДИКОВ В ОБЛАСТИ ГИПЕРБАРИЧЕСКОЙ ОКСИГЕНАЦИИ}

\section{Wissensstand einer auscewählten Gruppe von Medizinstudenten auf dem Gebiet DER HYPERBAREN SAUERSTOFFTHERAPIE}

\section{CONOCIMIENTOS DE UN GRUPO SELECCIONADO DE ESTUDIANTES DE MEDICINA EN EL CAMPO DE LA OXIGENOTERAPIA HIPERBÁRICA}

\author{
Gabriela Henrykowska, Andrzej Buczyński, Małgorzata Lewicka, Magdalena Zawadzka
}

Department of Epidemiology and Public Health, Medical University, Łódź, Poland Zakład Epidemiologii i Zdrowia Publicznego UM w Łodzi

\section{STRESZCZENIA / ABSTRACTS}

During the last decades, there has been a rapid development in the research and use of hyperbaric oxygen therapy (HBO), and modern medicine is increasingly taking advantage of its beneficial effects. The aim of the study was to check the level of knowledge of future doctors (medical students) on hyperbaric oxygen therapy.

The survey was conducted among 240 students of the medical faculty (3rd and 5th year of study) of the Military and Medical Faculty of the Medical University of Lodz. The author's questionnaire with forced-choice questions was used as research tool.

The students' knowledge of hyperbaric oxygen therapy was varied and in some cases was not dependent on the year of study. It was observed that students' knowledge of the subject matter depends on the number of teaching hours allocated to it.

Keywords: hyperbaric oxygen therapy (HBO), the knowledge of medical students

W ciagu ostatnich kilkudziesięciu lat nastapił gwałtowny rozwój w badaniach i stosowaniu terapii tlenem hiperbarycznym (ang. hyperbaric oxygen therapy, HBO), a współczesna medycyna coraz cześciej korzysta z jego dobroczynnego działania. Celem badania było sprawdzenie, co na temat tlenoterapii hiperbarycznej wiedzą przyszli lekarze (studenci medycyny).

Badanie ankietowe przeprowadzono wśród 240 studentów kierunku lekarskiego (III i V roku studiów) Wydziału Wojskowo-Lekarskiego Uniwersytetu Medycznego w Łodzi. Jako narzędzie wykorzystano autorski kwestionariusz ankiety zawierający pytania o kafeterii zamkniętej.

Wiedza studentów dotyczaca tlenoterapii hiperbarycznej była zróżnicowana i niektórych przypadkach nie była zależna od roku studiów. Zaobserwowano, że wiedza studentów z zakresu omawianej tematyki jest zależna od ilości godzin dydaktycznych na nią przeznaczonych.

Słowa kluczowe: terapia hiperbaryczna, wiedza studentów medycyny.

В последние несколько десятков лет произошел резкий скачок в развитии исследований и применения метода гипербарической оксигенации (анг. hyperbaric oxygen therapy, НВО), а современная медицина все чаще использует ее благотворное воздействие. Целью исследования была проверка знаний будущих врачей (студентов-медиков) о методе гипербарической оксигенации.

Анкетные исследования проводились среди 240 студентов медицинского факультета (III и V года обучения) военно-медицинского факультета Медицинского университета в г. Лодзь. В качестве инструмента был использован авторский опросник, содержащий вопросы закрытого типа.

Ключевые слова: гипербарическая терапия, знания студентов-медиков.

\section{ARTICLE INFO}

PolHypRes 201 Vol. 62 Issue 1 pp. 75 - 84

ISSN: 1734-7009 eISSN: 2084-0535

DOI: $10.2478 /$ phr-2018-0006

Pages: 10 , figures: 6 , tables: 0

page www of the periodical: www.phr.net.pl

Publisher

Polish Hyperbaric Medicine and Technology Society
Typ artykułu: oryginalny

Original article

Termin nadesłania: 02.12.2017 r.

Termin zatwierdzenia do druku: 14.01.2018 r. 
In den letzten Jahrzehnten hat sich die Forschung und der Einsatz der hyperbaren Sauerstofftherapie (HBO) rasant weiterentwickelt, und die moderne Medizin nutzt zunehmend ihre wohltuenden Wirkungen. Ziel der Studie war es, zu überprüfen, was zukünftige Ärzte (Medizinstudenten) über hyperbare Sauerstofftherapie wissen.

Die Umfrage wurde unter 240 Studenten der Studienfachrichtung Arzt (3. und 5. Studienjahr) des FB der Militärisch-Medizinischen Fakultät der Medizinischen Universität Lodz durchgeführt. Als Mittel diente ein Fragebogen, dessen Fragen geschlossenen Charakter aufwiesen.

Das Wissen der Studenten über die hyperbare Sauerstofftherapie war sehr unterschiedlich und in einigen Fällen nicht vom Studienjahr abhängig, sondern vielmehr von der Anzahl der Stunden, der diesem Bereich zugewiesen wurde.

Schlüsselwörter: Hyperbare Therapie, Kenntnisse von Medizinstudenten.

Durante las últimas décadas, ha habido un rápido desarrollo en la investigación y aplicación de la oxigenoterapia hiperbárica (OHB), y la medicina moderna aprovecha cada vez más sus efectos beneficiosos. El objetivo del estudio era comprobar los conocimientos de los futuros médicos (estudiantes de medicina) sobre la oxigenoterapia hiperbárica.

La encuesta se llevó a cabo entre un total 240 estudiantes de la facultad de medicina (III y V año de estudios) del Departamento Militar-Médico de la Universidad Médica de Łodz. Como herramienta utilizamos nuestro propio cuestionario con una serie de preguntas cerradas.

Los conocimientos de los estudiantes sobre la oxigenoterapia hiperbárica fueron variados y en algunos casos no dependieron del año de estudios. Se ha observado que el conocimiento de la materia por parte de los alumnos depende del número de horas lectivas que se le haya dedicado.

Palabras clave: terapia hiperbárica, conocimiento de los estudiantes de medicina. 


\section{WSTĘP}

Terapia tlenem hiperbarycznym (ang. hyperbaric oxygen - HBO) jest leczeniem polegającym na zastosowaniu tlenu pod ciśnieniem większym od 1 atm. w komorze hiperbarycznej. Podczas zabiegów leczniczych, w dostępnych obecnie komorach, ciśnienie wynosi zazwyczaj 2,5 ATA [1,2]. Dzięki temu można wielokrotnie zwiększyć ilość tlenu dostarczonego do komórek organizmu, gdyż chorzy $w$ trakcie zabiegu oddychają $100 \%$ tlenem. Tlen w warunkach hiperbarycznych jest dostarczany do komórek organizmu nie tylko przez utlenowanie hemoglobiny, ale i w postaci rozpuszczonej w osoczu krwi [3].

Wykazano, że w jednym litrze surowicy krwi znajdują się $3 \mathrm{ml}$ rozpuszczonego fizycznie tlenu. Wiadomym jest, że oddychając $100 \%$ tlenem w warunkach normobarii, wysycenie surowicy krwi tlenem wzrasta do $20 \mathrm{ml} / \mathrm{l}$. Pełne zapotrzebowanie organizmu będącego $\mathrm{w}$ spoczynku na tlen można zrealizować, oddychając 100\% tlenem w warunkach hiperbarii tlenowej, co prowadzi do wzrostu stężenia rozpuszczonego w surowicy tlenu do $50 \mathrm{ml} / \mathrm{l}[1,2,3,4$,$] .$

Wskazaniami do HBO są m.in.: choroba dekompresyjna, zatrucie tlenkiem węgla, zatorowość powietrzna lub inna gazowa, zgorzel gazowa, martwicze zakażenia tkanek miękkich, urazy wielonarządowe czy też oparzenia termiczne. trudno gojące się rany, stany wyjątkowo dużej utraty krwi, ropnie wewnątrzczaszkowe, martwicze zakażenia tkanek miękkich, oporne na leczenie zapalenia kości, późne uszkodzenia popromienne, zagrożone odrzuceniem przeszczepy skórne, oparzenia termiczne, promienicę $[5,6,7,8,9]$. Lista wskazań oraz przeciwwskazań do stosowania HBO, ustalona została w roku 2013 przez European Committee of Hyperbaric Medicine (ECHM) i jest cyklicznie aktualizowana, a Narodowy Fundusz Zdrowia refunduje leczenie hiperbaryczne.

Od wielu lat tlen hiperbaryczny jest wykorzystywany w procedurach leczniczych. Nie słabnie także zainteresowanie badaczy poszukiwaniem nowych możliwości praktycznego zastosowania procedur HBOT (ang. Hyperbaric Oxygen Treatment) [15].

Adepci medycyny powinni posiąść wiedze oraz praktyczne umiejętności $\mathrm{w}$ zakresie profilaktyki, diagnostyki i leczenia niezbędne do wykonywania zawodu lekarza, a stypendyści Ministerstwa Obrony Narodowej, dodatkowo, wiedzę niezbędną w pracy lekarza-oficera. Specyfiką pracy lekarza jest też ustawiczne kształcenie, aby jak najlepiej służyć pacjentom. Biorąc powyższe pod uwagę, wydaje się istotne sprawdzić jaką wiedzę $\mathrm{z}$ zakresu tlenoterapii hiperbarycznej posiadają studenci medycyny - przyszli lekarze.

\section{MATERIAŁ I METODY}

Badaniami objęto 240 studentów kierunku lekarskiego, Wydziału Wojskowo - Lekarskiego Uniwersytetu Medycznego w Łodzi. Do badania zostało losowo wybranych po 120 studentów z roczników III i V, $\mathrm{w}$ tym po 60 osób studiujących $\mathrm{w}$ ramach limitu miejsc Ministerstwa Obrony Narodowej (MON) z każdego analizowanego rocznika.

Narzędziem badawczym był autorski

\section{INTRODUCTION}

Hyperbaric oxygen therapy (HBO) is a treatment involving the use of oxygen at a pressure greater than $1 \mathrm{~atm}$. in a hyperbaric chamber. In the currently available chamber the pressure applied during therapeutic procedures commonly amounts to 2.5 ATA $[1,2]$. Thanks to this, it is possible to repeatedly increase the amount of oxygen delivered to the body's cells, as in the course of the treatment patients breathe with $100 \%$ oxygen. Oxygen under hyperbaric conditions is supplied to the body's cells not only through haemoglobin oxygenation, but also in the dissolved form in blood plasma [3].

It has been shown that one litre of blood serum contains $3 \mathrm{ml}$ of physically dissolved oxygen. It is known that by breathing $100 \%$ oxygen in normobaric conditions, the oxygen saturation of the blood serum increases to 20 $\mathrm{ml} / \mathrm{l}$. The full oxygen demand of an organism can be met by breathing $100 \%$ oxygen in hyperbaric conditions, which leads to an increase in the concentration of oxygen dissolved in the serum of up to $50 \mathrm{ml} / \mathrm{l}[1,2,3,4]$.

Indications for HBO include: decompression sickness, carbon monoxide poisoning, air or other gas embolism, gas gangrene, necrotic soft tissue infections, multi-organ injuries or thermal burns, wounds difficult to heal, states of an extremely high blood loss, intracranial abscesses, necrotising soft tissue infections, osteoarthritis resistant to treatment, late radiation injuries, skin grafts at risk of rejection, thermal burns, actinomycosis $[5,6,7,8,9]$. The list of indications and contraindications to the use of HBO, was established in 2013 by the European Committee of Hyperbaric Medicine (ECHM) and is regularly updated with the National Health Fund providing refunds on hyperbaric treatment.

Hyperbaric oxygen has been used in medical procedures for many years. The interest of researchers in looking for new possibilities of practical application of HBOT (Hyperbaric Oxygen Treatment) procedures is also unabated [15].

Individuals seeking to become medically proficient should acquire knowledge and practical skills in the field of prevention, diagnosis and treatment of medical conditions, these skills being necessary to function in the medical profession. Also, scholars of the Ministry of National Defence should additionally acquire the necessary knowledge to carry out the work of a doctor-officer. The specificity of the doctor's work is also constant education to best serve the patients. Taking the above into account, it seems essential to check the level of knowledge on hyperbaric oxygen therapy possessed by medical students - i.e. future doctors.

\section{MATERIAL AND METHODS}

The study covered 240 students of the medical faculty of the Military and Medical Department of the Medical University of Lodz. 120 students from both the $3 \mathrm{rd}$ and 5th years were randomly selected for the study, including 60 students studying within the framework of places limitation of the Ministry of National Defence (MON) from each analysed year.

The research tool was the authors' questionnaire containing 30 forced-choice questions concerned with hyperbaric oxygen therapy in the field of hyperbaric oxygen therapy and respondents' particulars. 
kwestionariusz ankiety o kafeterii zamkniętej zawierający 30 pytań z zakresu tlenoterapii hiperbarycznej oraz metryczkę.

Dokonano analizy statystycznej z użyciem $\mathrm{w}$ programu STATISTICA $12 \mathrm{PL}$, a poziom istotności przyjęto dla $\alpha=0,05$. Dla czytelnego zobrazowania, na wykresach, wyniki przedstawiono liczbowo, wskazując liczbę poprawnych i błędnych odpowiedzi uzyskaną w każdej grupie. W niniejszej pracy WWL - MON oznacza osoby studiujące $w$ ramach limitu miejsc Ministerstwa Obrony Narodowej, a skrót WWL - oznacza pozostałych („cywilnych”) studentów kierunku lekarskiego.

\section{WYNIKI I DYSKUSJA}

Terapię tlenem hiperbarycznym prowadzi się w komorach hiperbarycznych, które NFPA (National Fire Protction Association) podzieliło na trzy klasy: A - jednomiejscowe, B -wielomiejscowe oraz C - dla zwierząt [10,11]. Ankietowani studenci, którzy już zetknęli się $\mathrm{z}$ tematyką tlenoterapii hiperbarycznej (V rok) bez problemu wskazywali rodzaje komór hiperbarycznych $\quad(90 \%$ prawidło udzielonych odpowiedzi). Posiadali również podstawową wiedzę historyczną dotyczącą komór hiperbarycznych (75 \% poprawnych odpowiedzi). Niestety wiedza studentów III roku $\mathrm{w}$ tym zakresie była znikoma $(15 \%$ dobrych odpowiedzi).

Atmosferą bogatą w tlen określa się mieszaniny gazów, w których zawartość tlenu przekracza 23\%. Niestety, w badaniach własnych duża część studentów III roku nie potrafiła wskazać właściwej odpowiedzi (mino zrealizowania już przedmiotów takich jak biofizyka czy patofizjologia (ryc. 1).
A statistical analysis was performed using the STATISTICA 12 PL programme, and the significance level was assumed at $\alpha=0.05$. For clear data illustration in the graphs, the results are presented numerically, indicating the number of correct and incorrect answers obtained in each group. In this work, WWL - MON - refers to students studying within the places limitation of the Ministry of National Defence, whereas the abbreviation WWL - means other ("civilian") students of the medical faculty.

\section{RESULTS AND DISCUSSION}

Hyperbaric oxygen therapy is carried out in hyperbaric chambers, which the NFPA (National Fire Protective Association) has divided into three classes: A - single seater, B - multi-seater and C - dedicated for animals $[10,11]$. The surveyed students who have already encountered the topic of hyperbaric oxygen therapy (the 5 th year) easily indicated the types of hyperbaric chambers $(90 \%$ of the answers given). They also possessed basic historical knowledge on hyperbaric chambers $(75 \%$ correct answers). Unfortunately, the knowledge of third-year students in this field was insufficient (15\% of correct answers).

The atmosphere rich in oxygen is defined as gas mixtures in which the oxygen content exceeds 23\%. Unfortunately, in own study, a large part of the 3rd year students were unable to indicate the right answer (despite the already completed courses in biophysics or pathophysiology) (Fig. 1).

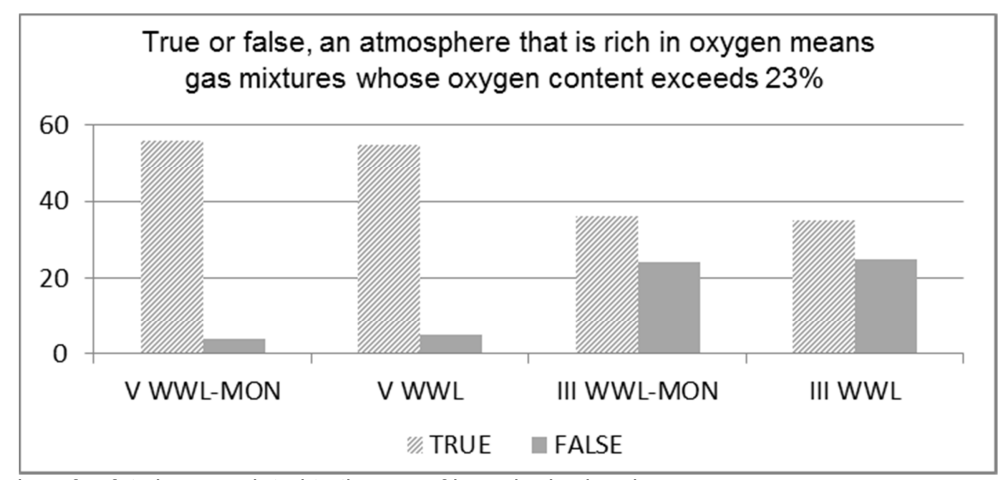

Fig. 1 The respondents' knowledge of safety issues related to the use of hyperbaric chambers.

Rys. 1 Wiedza ankietowanych z zakresu bezpieczeństwa w komorach hiperbarycznych.

Ze względów bezpieczeństwa, w komorach hiperbarycznych wieloosobowych, do wytworzenia ciśnienia stosuje się tylko powietrze. Aplikowanie tlenu pacjentom odbywa się poprzez kaptury ze szczelnymi gumowymi kołnierzami lub specjalne maski twarzowe. Przepisy dopuszczają $[10,11]$ używanie w nich mieszaniny oddechowej zawierającej maksymalnie 23\% tlenu, dzięki czemu możliwe jest stosowanie aparatury monitorującej, respiratorów i pomp infuzyjnych.

Wśród ankietowanych, znajomość tych przepisów bezpieczeństwa była zróżnicowana. Najlepsze wyniki uzyskali stypendyści MON z V roku - 58
For safety reasons, in multi-person hyperbaric chambers only air is used to generate the pressure. Oxygen is administered to patients through hoods with tight rubber collars or special face masks. The regulations allow $[10,11]$ to use in them a breathing mixture with a maximum oxygen content of $23 \%$, thanks to which it is possible to use monitoring equipment, respirators and infusion pumps.

Among the respondents, knowledge of these security regulations varied. The best results were obtained by the MON scholarship holders of the fifth year - 58 correct answers. Slightly fewer correct answers (55) 
prawidłowych odpowiedzi. Minimalnie mniej poprawnych odpowiedzi (55) uzyskali „cywilni” studenci tego roku. Wśród studentów III roku poprawność oscylowała ok. $50 \%$ - nie zależnie od grupy. Badani niezależnie od roku studiów, nie widzieli, że przy podwyższonym ciśnieniu, i w atmosferze bogatej w tlen, energia potrzebna do wywołania zapłonu jest niższa niż w warunkach normalnych. Liczba prawidłowych odpowiedzi w każdej grupie nie przekraczała 25 .

Dzięki odpowiednim możliwościom technicznym, pacjenci $\mathrm{z}$ objawami niewydolności oddechowej nie zostają pozbawieni możliwości korzystania z tlenoterapii hiperbarycznej. Istnieje kilka typów respiratorów, które są wykorzystywane w komorach hiperbarycznych [12]. Zaskakujące jest, że znaczna część studentów $\mathrm{V}$ roku nie potrafiła wskazać w ankiecie właściwej odpowiedzi (ryc. 2). were obtained by "civilian" students of this year. Among the students of the 3rd year, the correctness of answers oscillated around $50 \%$ - irrespective of the group. Regardless of the year of study, the respondents did not see that with elevated pressures and oxygen-rich atmospheres, the energy needed for an ignition was lower than in normal conditions. The number of correct answers in each group did not exceed 25.

Today, thanks to technical capabilities, patients with symptoms of respiratory failure are not deprived of the opportunity to use hyperbaric oxygen therapy. In fact, there are several types of respirators that are used in hyperbaric chambers [12]. It is surprising that a significant part of the 5th year students were unable to indicate the right answer in the survey (Fig. 2).

Fig. 2 Students' knowledge regarding the use of hyperbaric oxygen therapy in patients with respiratory failure.

Rys. 2 Wiedza studentów w zakresie stosowania tlenoterapii hiperbarycznej wśród pacjentów niestabilnych oddechowo.

Badanym studentom trudno było wskazać inne gazy, oprócz tlenu, stosowane w tlenoterapii hiperbarycznej. Jedynie studenci $\mathrm{V}$ roku, studiujący w ramach limitu MON nie mieli żadnych wątpliwości z wskazaniem właściwych odpowiedzi (ryc. 3). Może to wynikać ze zwiększonej ilości godzin dydaktycznych przeznaczonych na omawianą tematykę.
It was difficult for the surveyed students to indicate other gases, apart from oxygen, used in hyperbaric oxygen therapy. Only students of the 5 th year, studying within the framework of the places limitation programme of the Ministry of National Defence had no doubts indicating the right answers (Fig. 3). This may be due to the increased number of didactic hours allocated to the subject.

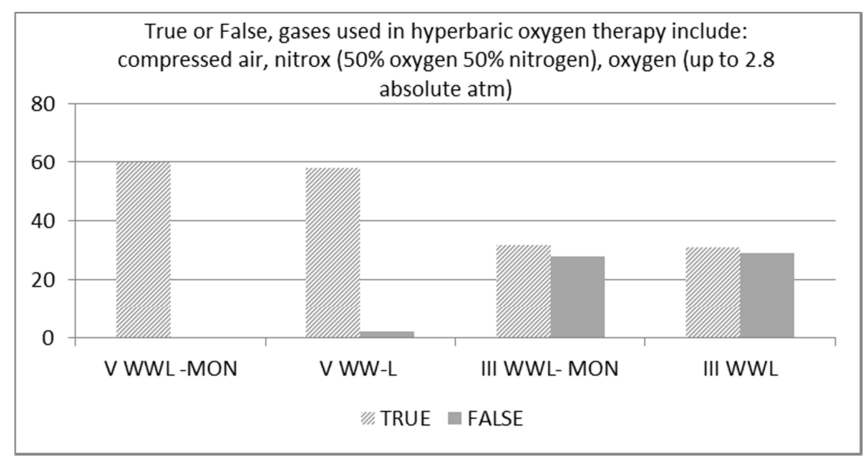

Fig. 3 Gases used in hyperbaric oxygen therapy according to the respondents.

Rys. 3 Gazy stosowane w tlenoterapii hiperbarycznej w opinii ankietowanych. 
Podobnie przedstawia się wiedz dotycząca przepisów prawno-organizacyjnych w zakresie tlenoterapii hiperbarycznej. Znacząca część studentów trzeciego roku nie wiedziała, iż tlenoterapia hiperbaryczna należy do świadczeń odrębnie kontraktowanych przez NFZ. Również nie byli świadomi wymagań NFZ dotyczących składu personelu medycznego ośrodka tlenoterapii hiperbarycznej (rys. 4) [6].
A similar situation is concerned with the knowledge of legal and organisational regulations in the field of hyperbaric oxygen therapy. A significant proportion of third-year students did not know that hyperbaric oxygen therapy belongs to services contracted separately by the NHF (National Health Fund). They were also unaware of the NHF requirements regarding the composition of the medical staff of hyperbaric oxygen therapy centres (Fig. 4) [6].

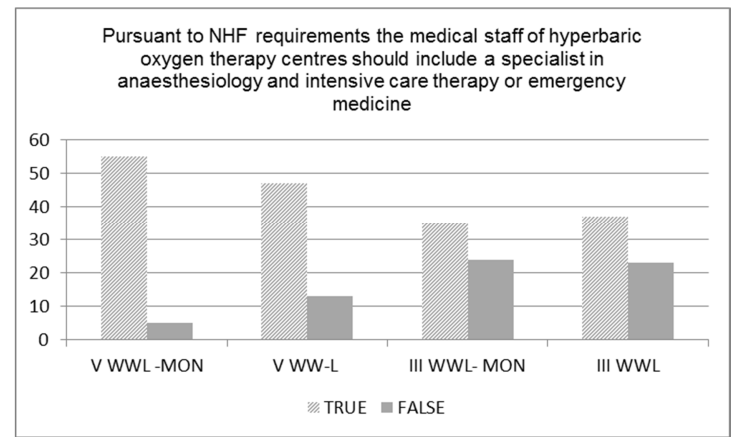

Fig. 4 Respondents' knowledge concerning the composition of the medical staff of a hyperbaric oxygen therapy centre.

Rys. 4 Wiedza ankietowanych dotycząca składu personelu medycznego ośrodka tlenoterapii hiperbarycznej.

Tlen hiperbaryczny działając na organizm ludzki, w zależności od zastosowanych parametrów fizycznych, wykazuje zarówno pozytywne jak i niekorzystne efekty. Korzyści dotyczą między innymi zmian w zakresie funkcjonowania układu krążenia, układu oddechowego, procesów związanych z gojeniem się przewlekłych ran. Zwiększenie utlenowania tkanek powoduje przyspieszenie proliferacji fibroblastów, przyspieszenie regeneracji niedokrwionych fragmentów skóry. Ponadto, przyspieszenie procesu ziarninowania i naskórkowania ran oraz nasilenie procesu angiogenezy, a także poprawę ukrwienia tętniczego i żylnego tkanek $[13,14]$.

Zdecydowana większość $(63,75 \%)$ studentów, zarówno III jak i $\mathrm{V}$ roku studiów potrafiła wymienić korzyści wynikające z działania podwyższonego ciśnienia parcjalnego tlenu. Ankietowani wskazywali na poprawę gojenia się ran $\mathrm{w}$ obszarach hipoksji, a także na zmniejszenie obrzęku w tkankach oparzonych.

Gojenie ran stanowi złożony a zarazem dynamiczny proces. Wyróżnić można trzy okresy: wysiękowego zapalenia (około $4 \mathrm{dni}$ od powstania rany), okres ziarniny (4-ty do 7-go dnia gojenia) oraz czas kształtowania się blizny. Całość niepowikłanego procesu gojenia rany trwa zazwyczaj około trzech tygodni od momentu jej powstania.

Wśród czynników zewnętrznych, istotnie wpływających na proces gojenia można wyróżnić sposób pielęgnacji rany. Wykazano istotną rolę bakterii beztlenowych w rozwoju zakażenia ran $[16,17]$. W warunkach podwyższonego ciśnienia tlen wywiera na bakterie beztlenowe działanie toksyczne. Przy zastosowaniu ciśnienia rzędu 2-3 ata obserwowano istotne zmniejszenie wzrostu beztlenowców $[3,18]$. Już w latach 60 ub. wieku, badania Winter i wsp. wykazały, że założenie na rany opatrunków przenikalnych dla tlenu znacznie przyspiesza procesy naprawcze $\mathrm{w}$ porównaniu do ran opatrywanych w standardowy sposób [19].
Depending on the physical parameters used, hyperbaric oxygen shows both positive and negative effects on the human organism. Benefits include changes in the functioning of the circulatory system, respiratory system, and processes related to the healing of chronic wounds. Increased tissue oxygenation accelerates fibroblast proliferation, thus accelerating the regeneration of ischaemic skin fragments. In addition, it results in the acceleration of granulation and wound skinning processes, intensification of the angiogenesis process, as well as improvement of blood supply to the arterial and venous tissues $[13,14]$.

The vast majority $(63.75 \%)$ of students, both in the 3rd and 5th year of study, were able to name the benefits resulting from the applied increased oxygen partial pressure. The respondents pointed to the improvement of wound healing in the areas of hypoxia, as well as the reduction of oedema in burnt tissues.

Wound healing is a complex and dynamic process consisting of three phases: exudative inflammation (about 4 days from wound formation), granulation (4th to 7 th day of healing) and scar formation. The entire uncomplicated wound healing process usually lasts about three weeks from its occurrence.

Among the external factors that significantly influence the healing process, one may distinguish the method of wound treatment. The important role of anaerobic bacteria in the development of wound infection has been demonstrated $[16,17]$. In the conditions of elevated pressure, oxygen exerts the toxic effect on anaerobic bacteria. At the pressure of 2-3 ata, a significant reduction in anaerobic growth has been observed $[3,18]$. Already in the 1960s studies by Winter et al. showed that the dressing of wounds with oxygen-permeable dressings significantly accelerates the repair processes as compared to wounds dressed in a standard manner [19]. 
Dlatego też, między innymi, wśród wskazań do tlenoterapii hiperbarycznej wymienić należy trudno gojące się rany $\mathrm{w}$ wyniku zespołu stopy cukrzycowej, a także zakażenia oraz martwicę kikuta po amputacji. Niestety, znaczna liczba studentów III roku jeszcze o tym nie wie (rys. 5).
Therefore, wounds difficult to heal should be mentioned among indications for hyperbaric oxygen therapy, including wounds resulting from diabetic foot syndrome, as well as infections and necrotic amputation stumps. Unfortunately, a significant number of thirdyears do not possess this knowledge yet (Fig. 5).

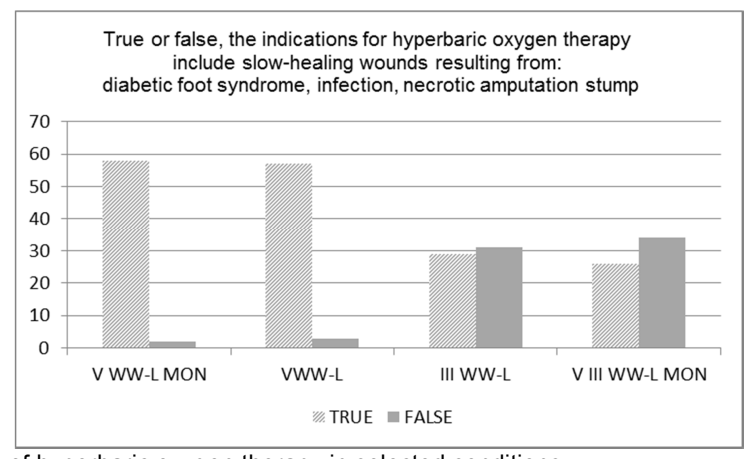

Fig. 5 Respondents' knowledge on the use of hyperbaric oxygen therapy in selected conditions.

Rys. 5 Znajomość stosowania tlenoterapii hiperbarycznej w wybranych schorzeniach.

Wzrastające zainteresowanie podwodnym światem, zwiększenie dostępności szkół nurkowych jak i szybki rozwój techniki nurkowej wiążą się, niestety, z rosnącą liczbą chorób i wypadków nurkowych. Choroba dekompresyjna (DSC) wywoływana jest desaturacją, czyli nagłym powstaniem w organizmie pęcherzyków gazu rozpuszczonych w tkankach podczas nurkowania. Połowa przypadków choroby dekompresyjnej ujawnia się $30 \mathrm{~min}$ po wynurzeniu, 90\% - do 3 godzin, 99\% - do 12 godzin, $100 \%$ - do 36 godzin [20]. DSC traktuje się jako stan nagłego zagrożenia życia. Do wypadku dochodzi zazwyczaj podczas zbyt szybkiego spadku ciśnienia (np. przy błędnym wynurzaniu). Jedyną skuteczną metodą leczenia choroby dekompresyjnej jest umieszczenie chorego $w$ komorze hiperbarycznej i poddaniu rekompresji $[3,21]$.

Hiperbaryczna terapia tlenowa wykorzystywana jest również jako podstawowa metoda leczenia zatrucia tlenkiem węgla $[8,21,22]$. Do zatrucia dochodzi najczęściej podczas pożaru i przebywaniu w zadymionym pomieszczeniu czy też w wyniku nieszczelności i braku sprawnej instalacji gazowej, a także nieszczelności przewodów wentylacyjnych. Średni czas półtrwania HbCO we krwi oddychając tlenem atmosferycznym, wynosi 5-6 godzin. Tlenoterapia 100\% tlenem skraca okres półtrwania $\mathrm{HbCO}$ do $30-90$ min. Natomiast tlenoterapia hiperbaryczna, przy oddychaniu 100\% tlenem pod ciśnieniem 2,5 ATA, skraca ten czas do 15-20 $\min [22]$.

Przy zatruciu tlenkiem węgla u ciężarnych, bez względu na okres ciąży, hiperbaryczna terapia tlenowa przy poziomie HbCO większym niż $10 \%$ powinna stanowić leczenie $\mathrm{z}$ wyboru. Stężenie karboksyhemoglobiny u płodu jest o 20-30\% większe niż u matki, a hemoglobina płodowa wykazuje większe powinowactwo do CO. Dlatego istotnym jest użycie tlenoterapii hiperbarycznej a nie tylko tlenoterapii biernej, która tylko redukuje $\mathrm{HbCO}$ u matki pozostawiając krew płodu wysyconą tlenkiem węgla $[3,23,24]$.

W badaniach własnych, prawie wszyscy ankietowani (234 osoby) wiedzieli, że właściwym postępowaniem leczniczym $w$ chorobie dekompresyjnej czy zatruciu tlenkiem węgla jest tlenoterapia
The growing interest in the underwater world, the increasing availability of diving schools and the rapid development of diving techniques unfortunately result in a growing number of diving-related diseases and accidents. Decompression sickness (DSC) is caused by desaturation, or a sudden formation of gas bubbles in the body which had previously dissolved in the tissues during a dive. Half of the cases of decompression sickness are revealed 30 min after surfacing, $90 \%$-up to 3 hours after, $99 \%$ - p to 12 hours after, $100 \%$ - up to 36 hours after [20]. DSC is treated as a condition of a sudden threat to human life. Accidents usually occur when the pressure drops too fast (for example as the result of an incorrectly performed ascent). The only effective method of treatment of decompression sickness is placing the patient in a hyperbaric chamber and subjecting him to recompression $[3,21]$.

Hyperbaric oxygen therapy is also used as a basic method of treatment of carbon monoxide poisoning $[8,21,22]$. The poisoning usually occurs as the result of being in a smoke filled room during a fire, or as a result of leaks or inoperative gas installations, as well as leaks in ventilation ducts. The average half-life of $\mathrm{HbCO}$ in the blood when breathing with atmospheric oxygen is 5-6 hours. Oxygen therapy with $100 \%$ oxygen reduces the half-life of $\mathrm{HbCO}$ to 30-90 min. Whereas the application of hyperbaric oxygen therapy with $100 \%$ oxygen at 2.5 ATA, shortens this time to 15-20 $\min$ [22].

In the case of carbon monoxide poisoning in pregnant women, regardless of pregnancy duration, hyperbaric oxygen therapy with HbCO levels exceeding $10 \%$ should constitute the treatment of choice. The foetal carboxyhemoglobin concentration is $20-30 \%$ higher than in the mother, and foetal haemoglobin has a higher affinity for CO. Therefore, it is important to use hyperbaric oxygen therapy and not merely passive oxygen therapy to reduce $\mathrm{HbCO}$ only in the mother, leaving foetal blood saturated with carbon monoxide $[3,23,24]$.

In own research, almost all of the respondents (234 people) knew that hyperbaric oxygen therapy constitutes proper therapeutic treatment in decompression sickness or carbon monoxide poisoning. 
hiperbaryczna. Niestety, 13-15 osób z każdej badanej grupy nie potrafiło wskazać czy kobiety ciężarne można poddać tlenoterapii hiperbarycznej w przypadku zatrucia CO (rys. 6)
Unfortunately, 13-15 people from each study group were unable to indicate whether pregnant women could undergo hyperbaric oxygen therapy in the case of CO poisoning (Fig. 6).

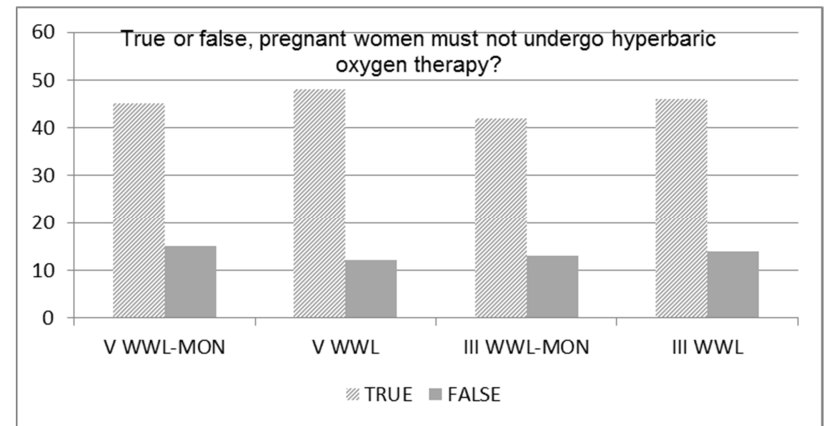

Fig. 6 Respondents' knowledge regarding the treatment of carbon monoxide poisoning.

Rys. 6 Znajomość postępowania w zatruciu tlenkiem węgla w opinii ankietowanych.

Innym wskazaniem do leczenia tlenoterapią hiperbaryczną jest nagła głuchota [25]. Do jej wystąpienia dochodzi najczęściej pomiędzy 30 a 50 rokiem życia, a częstotliwość występowania szacuje się na $5-20$ przypadków na $100 \quad 000$ ludności. HBO powoduje znaczący wzrost ciśnienia parcjalnego tlenu w tkankach, w tym przypadku w ślimaku, który jest bardzo wrażliwy na niedotlenienie. Komórki czuciowe ucha wewnętrznego uzależnione są od wychwytu tlenu $\mathrm{z}$ endolimfy drogą dyfuzji gdyż nie są bezpośrednio zaopatrywane w tlen drogą naczyniową. Zatem zwiększenie ciśnienia parcjalnego tlenu $\mathrm{w}$ endolimfie pod wpływem hiperbarii tlenowej może prowadzić do kompensacji niedoboru tlenu w tych komórkach $[3,26,27]$ Niestety, ponad $30 \%$ badanych studentów $\mathrm{V}$ roku i aż 55\% III roku nie wiedziało, że wskazaniem do leczenia tlenem hiperbarycznym są nagła głuchota oraz głuchota po urazie akustycznym.

Jednym z przeciwskazań względnych do HBO jest zapalenie zatok obocznych nosa. Niestety, mniej niż połowa $(n=28)$ ankietowanych studentów III roku i tylko $60 \% \mathrm{~V}$ roku potrafiło wskazać tę odpowiedź. Najwięcej prawidłowych odpowiedzi $(\mathrm{n}=38)$ uzyskano wśród stypendystów MON z V roku studiów. Uraz ciśnieniowy zatok przynosowych, głównie zatok czołowych, prawie zawsze wiąże się $\mathrm{z}$ ostrą infekcją błony śluzowej górnych dróg oddechowych. W stanach nagłych możliwe jest zastosowanie tlenoterapii hiperbarycznej z uwzględnieniem, że każde sprężenie musi być poprzedzone dokładną anemizacją błony śluzowej nosa i ujścia gardłowego trąbek słuchowych, a kompresja i dekompresja - prowadzone bardzo wolno $[5,27,28]$.

Badani mieli także trudności z określeniem czy HBO jest zalecana przy stanach zapalnych kości i szpiku kostnego. Jedynie $20 \%$ wszystkich ankietowanych udzieliło prawidłowych odpowiedzi. Podobnie kształtowała się wiedza badanych w zakresie stosowania tlenoterapii hiperbarycznej w popromiennym uszkodzeniu tkanek i narządów. Zaskakującym jest, że większość ankietowanych studentów zarówno III jak i V roku (odpowiednio $75 \%$ i 70\%) uznała, że osoby z rozrusznikami serca mogą bez przeszkód korzystać z HBO.
Another indication for treatment with hyperbaric oxygen therapy is sudden deafness [25]. Its occurrence is usually noted between 30 and 50 years of age, and the incidence rate is estimated at 5 - 20 cases per population of 100,000 . HBO causes a significant increase in oxygen partial pressure in tissues, in this case in the cochlea, which is very sensitive to hypoxia. Sensory cells of the inner ear depend on the oxygen uptake from endolymph by diffusion as they are not directly supplied with oxygen via blood vessels. Therefore, an increase of oxygen partial pressure in endolymph due to hyperbaric therapy may lead to oxygen deficiency in these cells $[3,26,27]$. Unfortunately, over $30 \%$ of the surveyed students of the 5 th year and as much as $55 \%$ of the 3 rd year did not know that the indication for hyperbaric oxygen treatment include sudden deafness and deafness as a result of an acoustic trauma.

One of the relative contraindications to HBO is inflammation of the paranasal sinuses. Unfortunately, less than half $(n=28)$ of the surveyed third year students and only $60 \%$ of the fifth year students indicated this answer. The majority of correct answers $(n=38)$ were obtained among the MON scholarship holders from the 5th year of study. Pressure trauma to the paranasal sinuses, mainly frontal sinuses, almost always involves an acute infection of the mucous membrane of the upper respiratory tract. In emergency situations it is possible to apply hyperbaric oxygen therapy, taking into account that each compression must be preceded by careful anemisation of the nasal mucosa and pharyngeal opening of the auditory tubes, and compression and decompression - which must to carried out very slowly $[5,27,28]$.

The subjects also had difficulty in determining whether HBO is recommended for inflammation of bone and bone marrow. Only $20 \%$ of all respondents gave correct answers. The knowledge of the subjects concerning the use of hyperbaric oxygen therapy in radiation damage to tissues and organs was similar. It is surprising that the majority of surveyed students of both the third and fifth year (75\% and $70 \%$ respectively) decided that individuals with pacemakers can freely use HBO. 


\section{WNIOSKI}

Wiedza studentów dotycząca tlenoterapii hiperbarycznej jest zróżnicowana i uzależniona od ilości godzin zajęć dydaktycznych przeznaczonych na tę tematykę. Duży wpływ mają także program studiów, a także indywidualne zainteresowania medycyną hiperbaryczną.

Istotnym jest zapoznanie studentów medycyny z podstawami fizycznymi tlenoterapii hiperbarycznej, badaniami naukowymi oraz doświadczeniami klinicznymi, poprzez zwiększenie ilości godzin dydaktycznych tematycznie związanych przedmiotów, tak aby zdobytą wiedzę mogli lepiej wykorzystać w swojej przyszłej pracy.

\section{Conclusions}

The knowledge of students regarding hyperbaric oxygen therapy varies and depends on the number of hours of didactic classes devoted to this subject. The programme of studies as well as individual interests in hyperbaric medicine also have a great impact.

It is important to familiarise medical students with the physical basics of hyperbaric oxygen therapy, scientific research and clinical experience, by increasing the number of teaching hours of thematically related subjects, so that the knowledge they acquire could be better used in their future work.

\section{REFERENCES}

Jain KK: Textbook of hyperbaric medicine. Wyd. 4. Hogrefe \& Huber Publishers, Göttingen 2004;

Mathieu D: Handbook on hyperbaric medicine. Springer, Dordecht 2006;

Sieroń A., Cieślar G., Kawecki M. (ed.) An outline of hyperbaric medicine. Publ. a-medica press, Bielsko-Biała 2007;

Boerema I, Meyne N, Brummelkamp W et al.: Life without blood: a study of the influence of high atmospheric pressure and hypothermia on dilution of the blood. J Cardiovasc Surg 1960; 1: 133-146;

5. Mathieu D, Marroni A, Kot J Tenth European Consensus Conference on Hyperbaric Medicine: recommendations for accepted and nonaccepted clinical indications and practice of hyperbaric oxygen treatment. Diving Hyperb Med, 2017, 47(1): 24-32. PMID: 28357821;

6. Ordinance of the President of the National Health Fund No. 88/2013/DSOZ of 18 December 2013 on defining the terms and conditions for concluding and implementing contracts such as: health services contracted separately;

7. Narożny W, Siebert J: The possibilities and limitations of the use of hyperbaric oxygen in medicine. Forum Med Rodz 2007; 1(4): 368-375;

8. Abramovich A, Shupak A, Ramon Y et al.: Hyperbaric.

dr n. med. Gabriela Henrykowska

Zakład Epidemiologii i Zdrowia Publicznego,

Uniwersytet Medyczny w Łodzi

gabriela.henrykowska@umed.lodz.pl 